\title{
Juvenile Chinook salmon (Oncorhynchus tshawytscha) growth in off-channel and main-channel habitats on the Sacramento River, CA using otolith increment widths
}

\author{
Michael P. Limm • Michael P. Marchetti
}

Received: 5 March 2008/Accepted: 31 March 2009/Published online: 29 April 2009

(C) The Author(s) 2009. This article is published with open access at Springerlink.com

\begin{abstract}
Few studies have quantified juvenile salmon growth among different habitats or evaluated the mechanisms controlling salmon growth and survival. We used otolith microstructure to compare daily relative growth rates among main-channel riverine areas, off-channel ponds, and non-natal seasonal tributaries of the Sacramento River, CA. We compared prey availability, prey preference, and stomach fullness between these sites. We observed larger average otolith growth increments, higher prey densities, and warmer water temperatures in both offchannel ponds and non-natal seasonal tributaries compared to the main-channel areas in both 2001 and 2002. Our findings suggest that warmer temperatures and abundant prey in off-channel habitats during Central Valley Chinook salmon rearing periods may lead to higher growth rates, which in turn may improve juvenile survival. Our results suggest that off-channel habitats may be critical habitats to include in conservation and management plans for juvenile salmon.
\end{abstract}

\footnotetext{
M. P. Limm ( $\bowtie)$

University of California,

3060 Valley Life Science Building,

Berkeley, CA 94720, USA

e-mail: mlimm@berkeley.edu

M. P. Marchetti

California State University,

Chico, 248 Holt Hall,

Chico, CA 95926, USA
}

Keywords Salmon $\cdot$ Chinook $\cdot$ Growth $\cdot$ Juvenile . Rearing $\cdot$ Habitat $\cdot$ Otolith

\section{Introduction}

Pacific salmon stocks show precipitous declines (e.g. Mantua et al. 1997). Declines are particularly severe in California, where subspecies, and/or populations of three anadromous salmonid species, Chinook salmon (Oncorhynchus tshawytscha), coho salmon ( $O$. kisutch) and steelhead trout (O. mykiss), currently have state or federal protection (Ruckelshaus et al. 2002). Yoshiyama et al. (2000) have documented a $75 \%$ decrease in the numbers of Chinook salmon in California's Central Valley since 1950. Much of this decline in the Central Valley is attributed to the reduction in spawning and rearing habitats, due to dams and diversions. (Yoshiyama et al. 2000).

Though anadromous salmon gain over $95 \%$ of their mass in the open ocean, recent modeling results for Columbia River Chinook suggest that first year and estuarine survival are key factors influencing a cohort's success (Kareiva et al. 2000). While regional differences exist between river systems, first year survival rates are likely important in the population dynamics of every salmonid stock (Holtby et al. 1990; Sommer et al. 2001). More information on juvenile salmonid performance in different habitats is needed to identify factors limiting their abundance during the freshwater phase (Swales et al. 1986). 
In addition to rearing in the main-channel of rivers, salmon rear in floodplains (e.g. Sommer et al. 2001), off-channel ponds (e.g. Peterson 1982), natal tributaries (e.g. Johnson et al. 1992), and non-natal tributaries (e.g. Murray and Rosenau 1989). It has been suggested that the refuge that off-channel habitats provide from both high flows and high sediment loads may improve growth rates (Crouse et al. 1981) and decrease mortality (Erman et al. 1988). In addition, at the onset of floodplain and seasonal tributary inundation, the increase in overall available habitat is likely to both reduce competition and lower predation risk (Sommer et al. 2001). Greater prey densities in offchannel habitat relative to the main-channel may also improve feeding rates and result in faster growth (Swales and Levings 1989). Rarely have the effects of off-channel habitats on juvenile salmon growth or survival been quantified (Simenstad and Cordell 2000). Instead, benefit for the salmonids is often assumed based on abundance comparisons between habitats rather than actual performance differences (Simenstad and Cordell 2000).

Recent advances in otolith increment analysis (Campana and Thorrold 2001) allow us to improve upon previous methods used to compare fish growth rates. Daily increment widths of sagittal otoliths provide a stable record of each individual's growth response to spatial and temporal environmental conditions (Neilson and Geen 1982; Neilson et al. 1985; Gauldie 1991). We can use these daily otolith growth increments to compare growth differences across a variety of habitats. One early concern with otolith analysis was that increment widths might be more influenced by temperature and metabolism than by somatic growth (Neilson and Geen 1982; Mosegaard et al. 1988; Wright et al. 1990; Bradford and Geen 1992). While otolith growth can become uncoupled from somatic growth under specific conditions (e.g. starvation), Gauldie (1991) demonstrated that changes in increment width do not correspond to predicted values based on temperature effects alone. As a result, otolith microstructure provides a conservative estimate of somatic growth and is a useful tool for assessing short-term relative growth differences between individuals or populations (Neilson et al. 1985; Gauldie 1991).

In the present study we use otolith daily growth increments as a relative measure of somatic growth in fall-run juvenile Chinook salmon. We hypothesized that somatic growth for salmon would be greater in offchannel habitats than in main-channel habitats. Specifically, we expected that the higher temperature, increased water clarity, and shallow depth of offchannel waters would support higher prey densities and favor increased somatic growth in juvenile salmon. To test this hypothesis we compared daily otolith growth increments, diet, and stomach fullness, prey abundance, temperature, and turbidity among mainchannel areas, off-channel ponds, and non-natal seasonal tributaries of the Sacramento River, California.

\section{Methods}

Study area

The Sacramento River is the largest river system in California and is also one of the most disrupted in the world (Yoshiyama et al. 2000). The river originates near Mt. Shasta and is fed primarily by snowmelt and precipitation runoff. The $70,000 \mathrm{~km}^{2}$ watershed is heavily altered by dams and diversions primarily for agriculture and urban development (Reisner 1986; May and Brown 2002). All fish sampling occurred between the towns of Los Molinos and Ord Bend at river miles 224 and 168 respectively (Fig. 1).

We focus on juvenile fall-run Chinook salmon due to the their use of off-channel habitats during the study period. Fall-run Chinook salmon have an "ocean-type" life history (Healey 1991) and are currently the largest of the four runs in the Sacramento River (Yoshiyama et al. 2000). Fall-run adult migration peaks during September and October and spawning occurs soon after adults reach their natal stream. After emerging in winter and early spring, the fall-run fry typically rear in main stem rivers or the bay-delta estuary before moving toward the ocean (Kjelson et al. 1982).

\section{Physical conditions}

Water temperature and turbidity and were measured at each site prior to sampling. We used a hand-held thermometer to measure water temperature. Additionally, in 2002, temperature loggers (Onset Corporation) were placed in all study sites taking hourly samples. Mean daily water temperature was calculated from the 24 daily measurements collected by these temperature 
Fig. 1 Sampling sites for March-April 2001 (open symbols) and FebruaryMarch 2002 (filled symbols) along the Sacramento River. Off-channel pond (squares), main-channel (stars), and non-natal seasonal tributaries (circles) are shown for each year

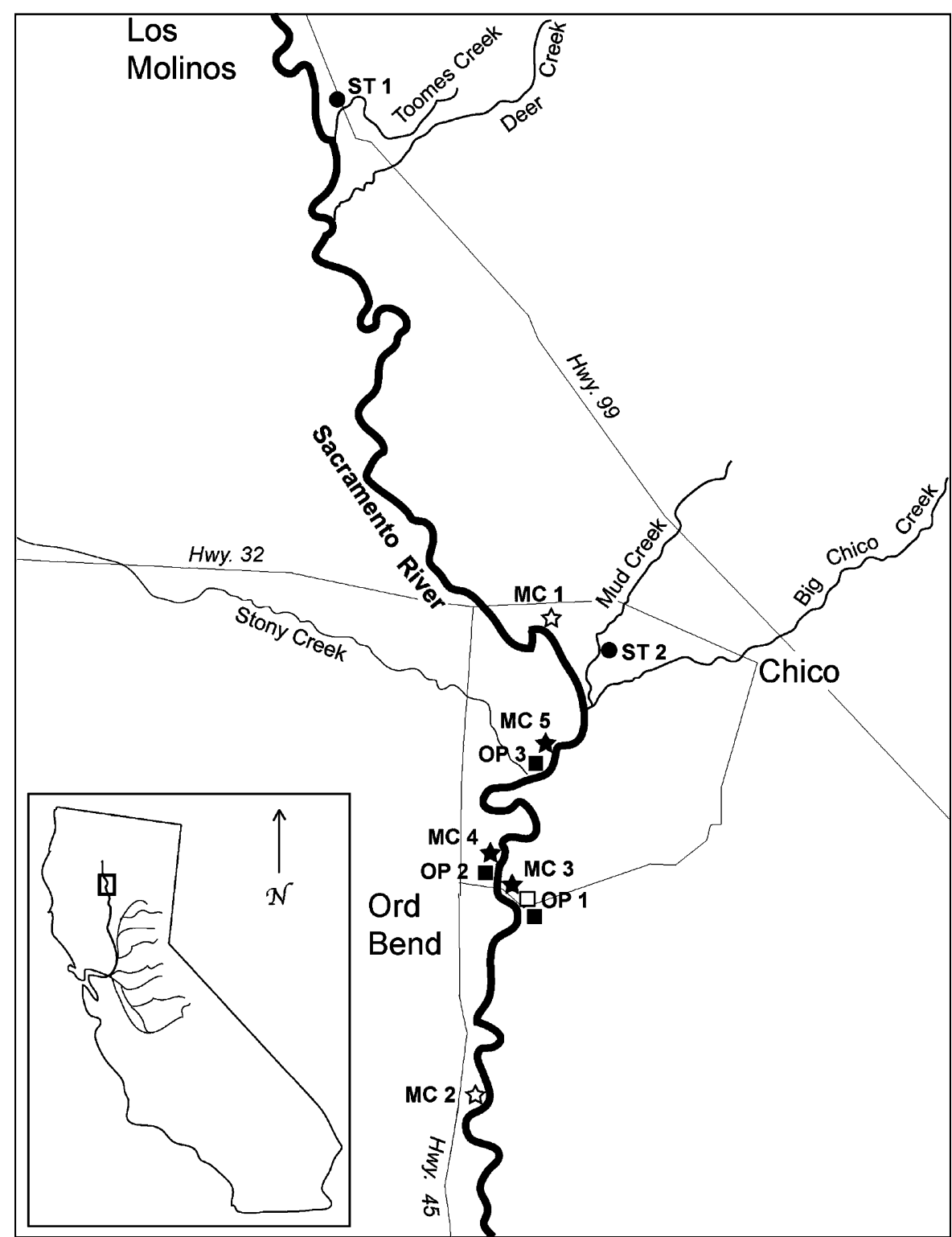

loggers. We measured turbidity using a DRT 15-CE Portable Turbidimeter.

Fish sampling

We collected fall-run juvenile salmon from three habitat types: main-channel, off-channel ponds, and non-natal seasonal tributaries. We sampled once every 14 days during March-April in 2001 and FebruaryMarch in 2002, using 10-m and 15-m long and 1.8-m high beach seines (4.75-mm mesh). We sampled in the morning between $07: 30$ to $11: 00$ so that more easily digestible prey would not be under-represented in fish stomachs. In 2001 and 2002 we visited each site three times and collected ten fish each visit, for a total of 30 fish site $^{-1}$ year $^{-1}$. Due to the possible correlation between fish length and increment width (larger fish having larger increments despite similar growth rates), we haphazardly collected ten fish between $40 \mathrm{~mm}$ and $50 \mathrm{~mm}$ standard length. Therefore, the fish lengths reported (Table 1) do not represent the mean fish standard length for each habitat.

In 2001 we sampled two main-channel sites and one off-channel pond site. The two main-channel sites (MC 1 and MC 2) were along side gravel bars on the 
Table 1 Results of physical measurements and salmon collections for 2001 and 2002

\begin{tabular}{|c|c|c|c|c|c|}
\hline & \multicolumn{2}{|l|}{2001} & \multicolumn{3}{|l|}{2002} \\
\hline & OP & $\mathrm{MC}$ & OP & $\mathrm{MC}$ & ST \\
\hline No. of sites & 1 & 2 & 3 & 3 & 2 \\
\hline Mean turbidity (NTU) & $5.7 \pm 2.7$ & $10.5 \pm 1.9$ & $7.8 \pm 2.0$ & $13.0 \pm 2.0$ & $5.0 \pm 2.5$ \\
\hline No. of salmon & 30 & 60 & 90 & 90 & 60 \\
\hline Standard length (mm) & $43.6 \pm 0.8$ & $44.1 \pm 1.0$ & $43.7 \mathrm{v} \pm 0.9$ & $40.7 \pm 0.6$ & $45.1 \pm 1.0$ \\
\hline Mean salmon mass (g) & $1.2 \pm 0.1$ & $1.3 \pm 0.1$ & $1.3 \pm 0.1$ & $1.0 \pm 0.1$ & $1.4 \pm 0.1$ \\
\hline Stomach fullness & $3.8 \pm 0.2$ & $3.7 \pm 0.3$ & $2.1 \pm 0.3$ & $1.7 \pm 0.3$ & $1.9 \pm 0.3$ \\
\hline Prey density (\# per $\mathrm{m}^{-3}$ ) & $97 \pm 42$ & $12 \pm 8$ & $316 \pm 164$ & $4.7 \pm 164$ & $23.4 \pm 201$ \\
\hline
\end{tabular}

Means are presented with \pm 1 SE. Note: Salmon standard length does not represent the mean for that habitat, but the mean for salmon selected (between $40 \mathrm{~mm}$ and $50 \mathrm{~mm}$ ) for otolith increment width analysis

$O P$ off channel ponds, $M$ main channel, $S T$ non-natal tributary

inside of a meander bend in the river (Fig. 1). Our offchannel pond site (OP 1) contained approximately $3,100 \mathrm{~m}^{3}$ of water and was continuously connected to the main-channel at the downstream end (Fig. 1). During the first week of sampling, high flows inundated off-channel pond 1 at the upstream end for 3 days.

In 2002 we sampled three new main-channel sites (erosion prevented sampling at 2001 main-channel sites), three off-channel pond sites (OP1 and two new sites OP2, OP3), and two non-natal seasonal-tributary sites (hereafter referred to as seasonal tributaries). Mainchannel sites (MC 3, MC 4, and MC 5) each occurred on gravel bars 100 meters upstream from an offchannel pond that was sampled (Fig. 1). The size of off-channel pond sites ranged from approximately $2,800 \mathrm{~m}^{3}$ (OP 2) to $5,500 \mathrm{~m}^{3}$ (OP 3). OP 1 and OP 2 lost their connection to the main-channel during the last week of sampling when discharge in the mainchannel dropped below $225 \mathrm{~m}^{3} \cdot \mathrm{s}^{-1}$. Our third site (OP 3) maintained connection to the main-channel throughout the study period.

We describe the seasonal tributaries as non-natal, based on evidence of juvenile salmon presence, but not reproduction, in a study by Maslin et al. (1997, Intermittent streams as rearing habitat for Sacramento River chinook salmon (Oncorhynchus tshawytscha). Unpublished report, California State University, Chico). Seasonal tributaries were connected to the main-channel by short periods of surface flow (typically December through May) and were characterized by 'flash' responses to precipitation. The
Toomes Creek site (ST1) is surrounded by mixed riparian forest dominated by cottonwoods, sycamores and willows, while the Mud Creek site (ST2) is situated in a freshwater marsh with willows and grasses as the predominant vegetation (Fig. 1).

Otoliths

Fish mass and standard length were measured prior to otolith removal. We followed Secor et al. (1992) for preparation of the otoliths. The right side otoliths were mounted on microscope slides in Crystalbond ${ }^{\mathrm{TM}}$ (Aremco, Valley Cottage, NY) with the sulcus acousticus facing down. The otolith was then polished using 600 wet grit sand paper followed by alumina micropolish $(0.05 \mu \mathrm{m}$ grit, Buehler ltd.). Polishing continued until central primordia and daily increments were clearly visible using light microscopy. The left otolith was used in six of the 330 samples because the right otolith was in the vaterite form rather than the more common aragonite form.

Each mounted otolith was assigned a random number to prevent bias during later analysis. We photographed otoliths at 400X using a Pixera Penguin (Pixera, Los Gatos, CA) digital camera mounted to an Olympus BX-51 compound microscope. Daily increment widths were measured using Metamorph $^{\circledR}$ (Molecular Devices Corp, Downington, PA) imaging analysis software and an average daily increment width (here after referred to as increment width) was calculated for each fish. We measured the ten most recently accreted daily increment widths to character- 
ize growth for each fish at each site. All measurements were made at a $45^{\circ}$ angle to the longitudinal axis at the posterior end, ventral side.

\section{Diet}

After otolith removal, we removed, weighed, and placed the stomach contents of each fish in $95 \%$ ethanol. Prey item identification followed Merritt and Cummins (1996) and Borror et al. (1992). Aquatic insect larvae and pupae were identified to scientific family, while aquatic adult insects, terrestrial insects, and crustaceans were identified to scientific order. Aquatic and terrestrial dipteran adults were all classified as winged diptera.

Individuals of the same taxon were grouped in a petri dish and the percent volume of each taxon relative to the total stomach contents was visually estimated. An Index of Relative Importance (IRI) was calculated for samples from each habitat using the frequency of occurrence, frequency by number, and percent volume for each prey category (Shreffler et al. 1992):

IRI $=$ freq. of occurrence (freq. by numbers * percent volume)

Due to small stomach size, we used percent volume of all ingested bolus rather than the standard measure of percent biomass (Shreffler et al. 1992).

An index representing stomach fullness (FI) was calculated by dividing the wet weight of stomach contents $\left(\mathrm{WW}_{\mathrm{sc}}\right)$ by the wet weight of the juvenile

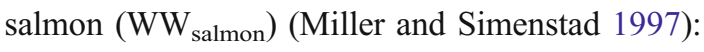

$\mathrm{FI}=\mathrm{WW}_{\mathrm{sc}} / \mathrm{WW}_{\text {salmon }} * 100$

Prey availability

Aquatic invertebrates in the water column were collected on every sampling occasion using $13 \mathrm{~cm}$ diameter plankton nets with $263 \mu \mathrm{m}$ mesh. Ten horizontal plankton net tows were made at different points within the habitat to sample microhabitat variation including depth and substrate. Each plankton tow was $10 \mathrm{~m}$ in length gauged from the rope length. In flowing water, we applied a Lagrangian approach and sampled a $10 \mathrm{~m}$ long water column perpendicular to the shore. While pulling the plankton net in towards the shore we moved downstream with the current, keeping the rope at a $90^{\circ}$ angle with respect to the shore. The ten samples were combined into a single composite sample and preserved in $90 \%$ ethanol. Due to high numbers of organisms, three samples from backwater sites in 2001 and 2002 were subsampled in the lab. Subsampling was accomplished by measuring the total sample volume, agitating the sample for $10 \mathrm{sec}$ and removing a subsample of known volume with a pipet. Subsampling continued until 300 organisms were counted, after which the last subsample was fully identified. Identification of available prey organisms followed the same procedures as for stomach contents.

Data analysis

In 2001 we captured salmon from only one off-channel pond. We used Student's t-test to compare otolith increment width, prey availability, stomach fullness, temperature, and turbidity between the off-channel pond and main-channel sites. In 2002, we performed analysis of variance (ANOVA) on otolith increment width to test hypotheses about prey availability, stomach fullness, temperature, and turbidity between the three habitat types. We used Tukey's multiple comparison test to compare habitat means at a 0.05 significance level. We used analysis of covariance (ANCOVA) to test for covariance between habitat and salmon length.

For prey availability comparisons, we limited prey taxa to those that constituted $96 \%$ IRI or greater in the salmon stomachs. We tested for differences between discrete temperature measurements and daily averages from temperature loggers using Wilcoxon's matchedpairs test. All statistical analyses were done using JMP 5.0 (SAS Institute Inc.).

\section{Results}

Physical measurements

No differences were found between hand-held temperature measurements and daily averages calculated from temperature loggers $(p>0.56)$. In 2001 mean water temperatures were significantly higher in OP 1 than in the main-channel habitats $\left(\mathrm{MC} 1 \mathrm{t}_{1,4}=4.39\right.$, $p=0.01$; with MC $2 \mathrm{t}_{1,4}=3.51, p=0.02$, Fig. 2). Water temperatures in 2002 were significantly higher in off- 
channel ponds than in the main-channel and seasonal tributaries $\left(\mathrm{F}_{2,5}=8.97, p=0.02\right.$, Tukey's, Fig. 2), with the highest temperatures found in the off channel ponds followed by seasonal tributaries. In 2001 turbidity in OP 1 was lower than in MC $1\left(\mathrm{t}_{1,4}=\right.$ 2.48, $p=0.02)$ and similar to MC $2\left(\mathrm{t}_{1,4}=1.69,0.10\right.$, $p=0.02$ Table 1). Turbidity was similar between habitats in $2002\left(\mathrm{~F}_{2,5}=3.32, p=0.12\right)$.

Otolith increments

In 2001 we measured a significant difference in otolith increment width between habitat types (between OP 1 and MC $1 \mathrm{t}_{1,58}=5.18, p<0.0001$; between OP1 and MC $1 \mathrm{t}_{1,58}=2.82, p=0.003$ ), with larger otolith increment widths observed in individuals captured in off-channel ponds (Fig. 2). In 2002 otolith increment width again differed between habitat types $\left(\mathrm{F}_{2,5}=9.12, p=0.02\right)$, with larger otolith increment widths observed in off-channel pond salmon
(Tukey's, $\alpha=0.05$ ). Individuals captured in seasonal tributaries had more variable increment widths, and did not differ significantly from either off-channel ponds or main-channel salmon (Tukey's, $\alpha=0.05$ ). ANCOVA results suggest no interaction between habitat and salmon length was observed, and therefore habitat effects on daily increment widths were independent of salmon length.

Diet

Aquatic dipterans dominated juvenile salmon diets in all habitats (Fig. 3). In 2001 Chironomidae larvae, pupae, and adults were the most common prey items in both off-channel pond salmon (69\% IRI) and mainchannel salmon (78\% IRI). Diets in 2002 were again dominated by Chironomidae larvae and pupae, with IRI values of $52 \%, 97 \%$, and $89 \%$ for off-channel pond, main-channel and seasonal-tributary salmon, respectively. Copepods were also a significant prey
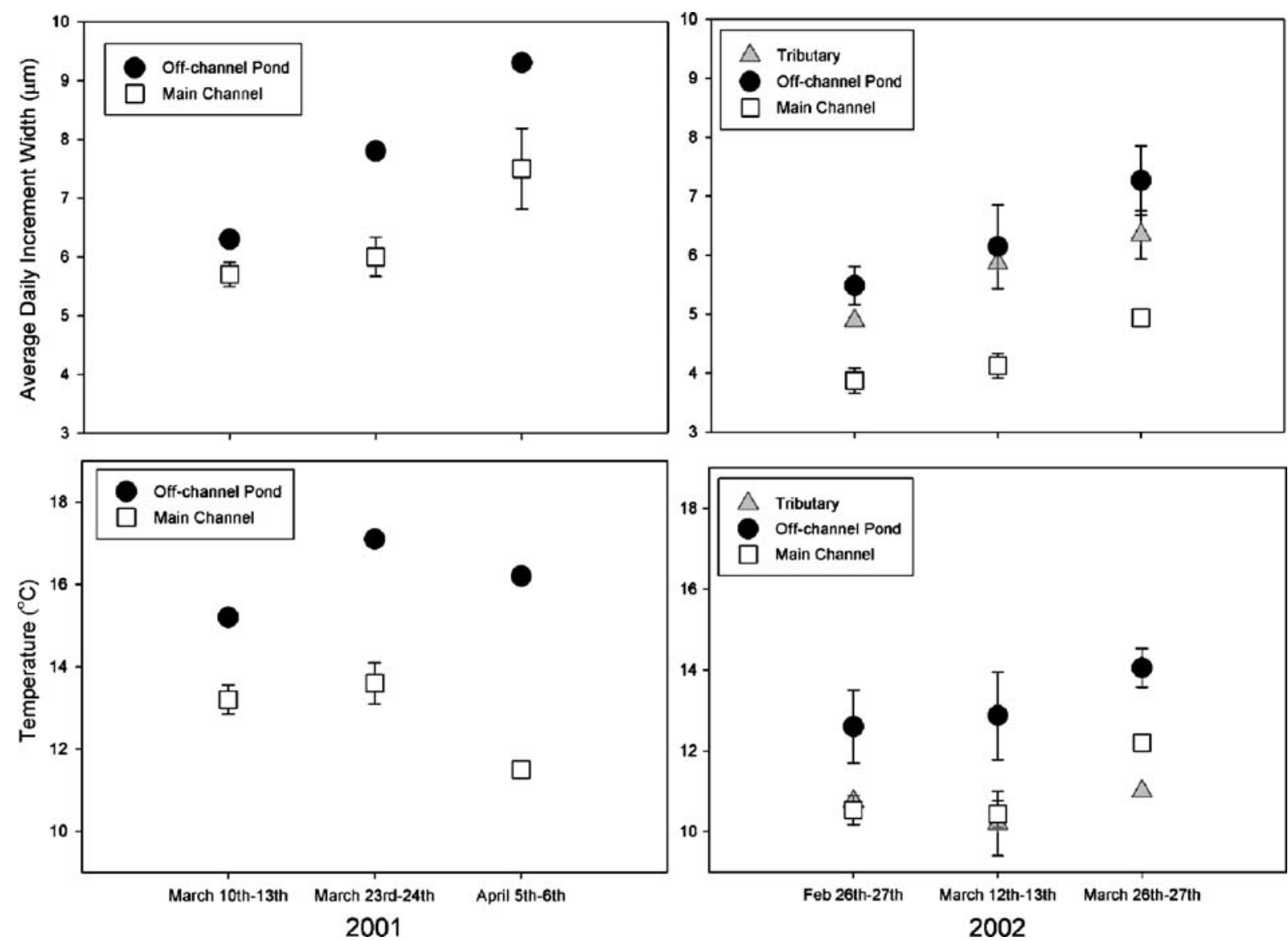

Fig. 2 Mean daily increment widths and temperature for different habitats in 2001 and 2002. Error bars are calculated from site means 
Fig. 3 Chinook salmon diet in off-channel ponds and the main-channel during March-April of 2001 and in off-channel ponds, the main-channel, and non-natal seasonal tributaries during February-March of 2002. The Index of Relative Importance (IRI) is defined in the text
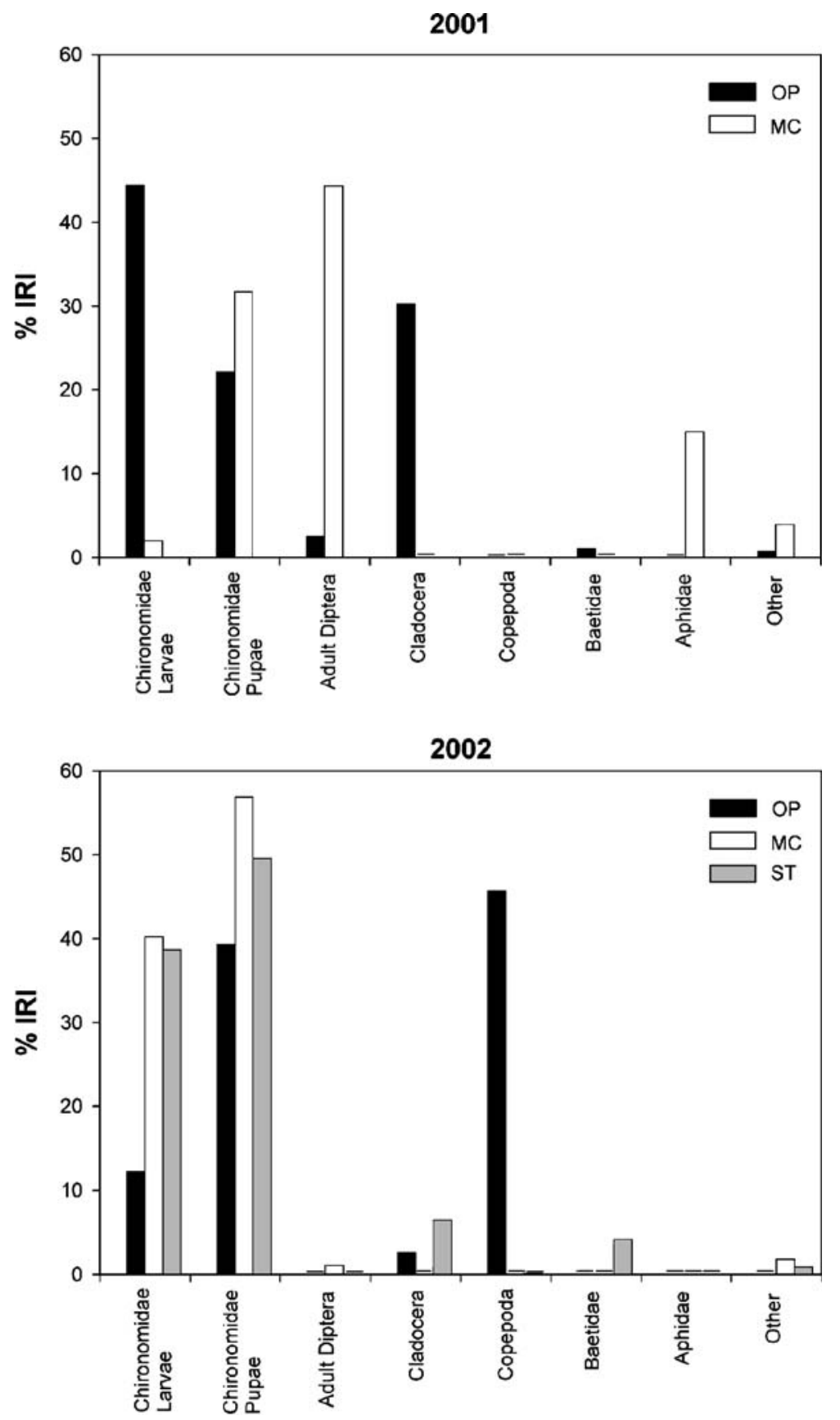

item in off-channel pond salmon stomachs (46\%). Hydropsychidae larvae (Trichoptera), Baetidae nymphs (Ephemeroptera), and arachnids were consumed infrequently in both years.

We observed no difference in stomach fullness between habitats in 2001 (between OP 1 and MC 1 $\mathrm{t}_{1,4}=1.39, p=0.09$; between OP 1 and $\mathrm{MC} 1 \mathrm{t}_{1,4}=0.97$, $p=0.16$, Table 1$)$ or in $2002\left(\mathrm{~F}_{2,5}=1.68, p=0.19\right)$.
Prey availability

We observed higher prey densities in off-channel habitats in both years but the differences were not statistically significant due to high between-sample variability (In 2001 between OP 1 and MC $1 \mathrm{t}_{1,4}=$ 2.00, $p=0.09$; between OP 1 and $\mathrm{MC} 1 \mathrm{t}_{1,4}=2.05, p=$ 0.16 ; In $2002 \mathrm{~F}_{2,5}=1.07, p=0.41$ ), Table 1). 
Cladocerans and copepods were the dominant taxa found in all habitats followed by chironomidae larvae. In both years, cladoceran and copepod densities were over a magnitude greater in off-channel ponds than in the main-channel. Copepods dominated off-channel pond zooplankton in 2001 and cladocerans in 2002.

Chironomidae larvae were the second most common prey in all habitats followed by chironomidae pupae. In 2001, chironomidae larval densities in offchannel ponds were similar to those in main-channel habitats, while in 2002 they were three times the main-channel density and one-third the seasonaltributary density.

\section{Discussion}

The primary result of the current study indicates that, Chinook salmon in the Sacramento River show larger otolith increments widths in off-channel habitats when compared to near-by main-channel habitat, suggesting faster or improved growth rates. This result is interesting in the light of previous work on the benefits of alternative habitat for juvenile salmonids. Our results based on otolith microstructure support the findings of previous studies using alternative methods to evaluate growth improvements such as changes in abundance (Simenstad and Cordell 2000), change-in-length of fish (Swales et al. 1986; Murray and Rosenau 1989) and mark/recapture techniques (Sommer et al. 2001; Wigington et al. 2006).

A suite of environmental, genetic and behavioral factors likely influence salmonid growth rates. In our case the juvenile salmon rearing in off-channel habitats clearly experienced warmer water temperatures both within and between years (Fig. 2). Warmer temperature by itself is known to increase metabolic and growth rates when adequate food is present. For example, in the laboratory under maximum ration conditions, Central Valley salmon growth rates increase with increasing water temperature up to $19^{\circ} \mathrm{C}$ (Rich 1987; Cech and Myrick 1999). Our results suggest that water temperature differences (including seasonal variation) may have played a role in growth rate differences between habitats.

Water temperature also influences metabolism and therefore indirectly affects somatic growth (Elliot 1982). We quantified juvenile salmon somatic growth by measuring daily otolith increment widths. While water temperature can decouple otolith growth from somatic growth and complicate otolith microstructure interpretation (Marshall and Parker 1982; Mosegaard et al. 1988; Bradford and Geen 1992), otolith growth cannot be predicted by water temperature alone. To investigate the effect of temperature on otolith increment widths, Gauldie (1991) reared juvenile Chinook salmon at five different water temperatures $\left(8^{\circ} \mathrm{C}, 10^{\circ} \mathrm{C}\right.$, $12^{\circ} \mathrm{C}, 14^{\circ} \mathrm{C}$, and $16^{\circ} \mathrm{C}$ ) and fed them to repletion. After 43 days the otoliths were analyzed and an empirical relationship between temperature and otolith increment width was developed. If we assume water temperature is the sole control on otolith increment width growth, we can apply the water temperature data from our study to Gauldie's equation (Average Increment Width $=1.19+0.085 *$ Temperature $)$ and predict otolith increment widths for juvenile salmon in each habitat type. Based on the average water temperature in each habitat, off-channel pond salmon otolith increment widths should be $12 \%$ wider in 2001 and $8 \%$ wider in 2002 , than otolith increment widths in main-channel salmon. Seasonal tributary salmon otolith increment widths should be $2 \%$ narrower than those in main-channel salmon. The observed otolith increment widths were $21 \%$ wider in off-channel pond salmon in 2001, 46\% wider in off-channel pond salmon in 2002 , and $10 \%$ wider in seasonal tributary salmon in 2002 than those in main channel salmon. The greater otolith increment width differences we observed in offchannel habitats relative to those predicted, suggest factors other than water temperature influenced otolith growth rates.

Salmon growth rates may also be influenced by prey availability. Higher metabolic rates require adequate food to maintain higher growth rates. Our observations of higher prey densities in the warmer off-channel habitats are congruent with previous research on innundated floodplains (Gladden and Smock 1990; Sommer et al. 2001) and shallow habitat interfaces (Welcomme 1979). We expected to see greater stomach fullness in habitats with greater prey densities due to higher feeding rates. Stomach fullness was higher in both off-channel ponds and main-channel habitats in 2001 than in 2002 but did not vary significantly within the year. While stomach fullness results imply that prey availability did not influence growth differences between habitats, it is possible that salmon fed at different times or for 
different duration(s) in different habitats, or that prey availability varied throughout the day in different habitats. Salmon movement between habitats may have influenced stomach contents, but recent analysis of chironomid and salmon carbon and nitrogen stable isotopes, which provide a time-integrated measure of prey assimilation (Vander Zanden and Vadeboncoeur 2002), suggest the chironomids and salmon we collected were feeding from distinct sources that differed between habitats (Limm, unpublished data). Because stomach evacuation rates and digestive processes are temperature dependent (Elliot and Persson 1978), fishes with full stomachs that were collected in warmer conditions (i.e., off-channel habitats) likely processed food more quickly than did salmon with full stomachs collected in cooler locations (i.e., main-channel).

Turbidity and habitat area may also influence growth rate. It is known that fine suspended sediments can reduce salmonid growth rates (Crouse et al. 1981) and feeding efficiency (Berg and Northcote 1985). Berg and Northcote (1985) observed reduced feeding efficiency at turbidity levels as low as 11 NTU. These levels of turbidity were observed in the main-channel during the study period in both 2001 and 2002. In addition to effecting growth, high turbidity may cause juvenile salmon to select less-turbid off-channel sites during high flows (Scrivener et al. 1994). The inundation of seasonally dry areas habitats (including floodplains, off-channel ponds, and tributaries) increases the overall wetted area available for fish and other aquatic organisms and may increase prey availability (Sommer et al. 2001). This same increase in wetted area may also act to dilute the number of predators and their direct and indirect impacts on juvenile salmon. Large predators may force smaller fishes into sub-optimal feeding areas (Schlosser 1987), so habitat expansion that reduce this interaction and could act to accelerate the growth of smaller fish.

The shallower depths, warmer temperatures, lower turbidity, and more abundant prey we found in offchannel remnant floodplain habitats likely support higher productivity of both salmonid and nonsalmonid species. Floodplains elsewhere enhance fish growth (Welcomme 1979; Gutreuter et al. 2000; Sommer et al. 2001), secondary production (Gladden and Smock 1990), and contribute significant aquatic biomass to the river system (Benke 2001). Whether the enhanced fish growth we observed in off-channel habitats yields a significant biomass contribution to main channel communities is unclear. We observed black bass (Micropterus ssp.) in off-channel ponds and predation by black bass (e.g. Tabor et al. 2007) may offset any rearing benefits for juvenile Chinook. We also observed stranding of juvenile salmon in both 2001 and 2002 as off-channel ponds were disconnected from the main-channel, and water temperatures increased to lethal limits $\left(\approx 24^{\circ}\right.$; Rich 1987). The extensive alteration of the Sacramento River's natural flow regime has greatly decreased connectivity to offchannel habitats in the spring (Yoshiyama et al. 2000). If salmon life history strategies are adapted to utilizing off-channel habitats, the mortality costs associated with high temperatures and stranding may be significant (Higgins and Bradford 1996).

In conclusion, off-channel habitats have historically played a critical/crucial role in supporting juvenile fishes (both salmon and non-salmonids) in the Central Valley of California. Our results support the idea that off-channel habitats may be critical areas to include in conservation and management plans for juvenile salmon. We see evidence in our study and others (Sommer et al. 2001) to support the idea that higher rates of growth occur in off-channel habitats. Increased growth in fishes is also typically linked to higher rates of survival (Parker 1971). Future work in this system will be needed to examine this linkage in more detail and perhaps ultimately provide estimates of the impact that rearing in these habitats has on juvenile survival (Simenstad and Cordell 2000). Historically we can assume that off-channel habitats were once integral pieces of the environmental mosaic of the Sacramento River. As a result any habitat remnants that remain are likely important to the rearing of Central Valley salmonids, and that restoration and management of these types of habitat should be included in an overall conservation strategy aimed at restoring California's salmonids.

Acknowledgements We are indebted to the following people who made this project successful. We would like to thank P. Maslin for his extensive knowledge of the Sacramento River and off-channel habitats. Appreciation goes to J. Hobbs and S. Campana for their consultation on analyzing otolith microstructure. We would like to thank J. Bonesio, J. Burghardt, J. Grig, R. Brown, and E. Burns for their help with fieldwork. Thanks to W. Sousa for help with the analysis. We would like to thank G. Golet, T. Sommer, R. Yoshiyama, W. Palen, and M. Power for critically reviewing the manuscript. The study was funded by The Nature Conservancy. 
Open Access This article is distributed under the terms of the Creative Commons Attribution Noncommercial License which permits any noncommercial use, distribution, and reproduction in any medium, provided the original author(s) and source are credited.

\section{References}

Benke AC (2001) Importance of flood regime to invertebrate habitat in an unregulated river-floodplain ecosystem. J N Am Benthol Soc 20:225-240. doi:10.2307/1468318

Berg L, Northcote TG (1985) Changes in territorial, gill-flaring, and feeding behavior in juvenile coho salmon (Oncorhynchus kisutch) following short-term pulses of suspended sediment. Can J Fish Aquat Sci 42:1410-1417. doi:10. 1139/f85-176

Borror DJ, Triplehorn CA, Johnson NF (1992) An introduction to the study of insects, 6th edn. Saunders College Publishing, Fort Worth

Bradford MJ, Geen GH (1992) Growth estimates from otolith increment widths of juvenile chinook salmon (Oncorhynchus tshawytscha) reared in changing environments. J Fish Biol 41:825-832. doi:10.1111/j.1095-8649.1992.tb02710.x

Campana SE, Thorrold SR (2001) Otoliths, increments, and elements: keys to a comprehensive understanding of fish populations? Can J Fish Aquat Sci 58:30-38. doi:10.1139/ cjfas-58-1-30

Cech JJ, Myrick CA (1999) Steelhead and chinook salmon bioenergetics: temperature, ration, and genetic effects. Davis, Ca. Research report to the University of California Water Resources Center

Crouse MR, Callahan CA, Malueg KW, Dominguez SE (1981) Effects of fine sediments on growth of juvenile coho salmon in laboratory streams. Trans Am Fish Soc 110:281-286

Elliot JM (1982) The effects of temperature and ration size on the growth and energetics of salmonids in captivity. Comp Biochem Physiol Part B 73:81-91. doi:10.1016/03050491(82)90202-4

Elliot JM, Persson L (1978) The estimation of daily rates of food consumption for fish. J Anim Ecol 47:977-991. doi: $10.2307 / 3682$

Erman DC, Andrews ED, Yoder-Williams M (1988) Effects of winter floods on fishes in the Sierra Nevada. Can J Fish Aquat Sci 45:2195-2200

Gauldie RW (1991) The morphology and periodic structures of the otolith of the chinook salmon (Oncorhynchus tshawytscha), and temperature dependent variation in otolith microscopic growth increment width. Acta Zoologica 72:159-179

Gladden JE, Smock LA (1990) Macroinvertebrate distribution and production on the floodplain of two lowland headwater streams. Freshw Biol 24:533-545. doi:10.1111/j.13652427.1990.tb00730.x

Gutreuter S, Bartels AD, Irons K, Sandheinrich MB (2000) Evaluations of the flood-pulse concept based on statistical models of growth of selected fishes of the Upper Mississippi River system. Can J Fish Aquat Sci 56:2282-2291. doi:10.1139/cjfas-56-12-2282
Healey MC (1991) Life history of chinook salmon. In: Groot C, Margolis L (eds) Pacific salmon life histories. University of British Colombia Press, Vancouver, pp 311-394

Higgins PS, Bradford MJ (1996) Evaluation of a large scale fish salvage to reduce the impacts of controlled flow reduction in a regulated river. $\mathrm{N}$ Am $\mathrm{J}$ Fish Manage 16:666-673. doi:10.1577/1548-8675(1996)016\&1t;0666: EOALSF\&gt;2.3.CO;2

Holtby LB, Anderson BC, Kadowaki RK (1990) Importance of smolt size and early ocean growth to interannual variability in marine survival of coho salmon (Oncorhynchus kisutch). Can J Fish Aquat Sci 47:2181-2194. doi:10.1139/f90-243

Johnson SW, Thedinga JF, Koski KV (1992) Life History of Juvenile Ocean-Type Chinook Salmon (Oncorhynchus tshawytscha) in the Situk River, Alaska. Can J Fish Aquat Sci 49:2621-2629. doi:10.1139/f92-290

Kareiva P, Marvier M, McClure M (2000) Recovery and management options for spring/summer chinook salmon in the Columbia River Basin. Science 290:977-979. doi:10.1126/science.290.5493.977

Kjelson MA, Raquel PF, Fisher FW (1982) Life history of fall-run juvenile chinook salmon, Oncorhynchus tshawytscha, in the Sacramento-San Joaquin Esturary, California. In: Kennedy VS (ed) Estuarine comparisons. Academic, New York

Mantua NJ, Hare SR, Zhang Y, Wallace JM, Francis RC (1997). A Pacific interdecadal climate oscillation with impacts on salmon production. Bull Am Met Soc 78:1069-1079

Marshall SL, Parker, SS (1982) Pattern identification in the microstructure of sockeye salmon (Oncorhynchus nerka) otoliths

May JT, Brown LR (2002) Fish communities of the Sacramento River Basin: Implications for conservation of native fishes in the Central Valley, California. Environ Biol Fishes 63:373-388. doi:10.1023/A:1014964318485

Merritt RW, Cummins KW (1996) An introduction to the aquatic insects of North America, 3rd edn. Kendall/Hunt, Dubuque, Iowa

Miller JA, Simenstad CA (1997) A comparative assessment of a natural and created estuarine slough as rearing habitat for juvenile chinook and coho salmon. Estuaries 20:792-806. doi: $10.2307 / 1352252$

Mosegaard H, Svedang H, Taberman K (1988) Uncoupling of somatic and otolith growth-rates in arctic char (Salvelinus alpinus) as an effect of differences in temperature response. Can J Fish Aquat Sci 45:1514-1524. doi:10.1139/f88-180

Murray CB, Rosenau ML (1989) Rearing of juvenile chinook salmon in non-natal tributaries of the Lower Fraser River, British Columbia. Trans Am Fish Soc 118:284-289. doi:10.1577/1548-8659(1989)118<0284:ROJCSI $>2.3$.CO;2

Neilson JD, Geen GH (1982) Otoliths of chinook salmon (Oncorhynchus tshawytscha): daily growth increments and factors influencing their production. Can J Fish Aquat Sci 39:1340-1347

Neilson JD, Geen GH, Bottom D (1985) Estuarine growth of juvenile chinook salmon (Oncorhynchus tshawytscha) as inferred from otolith microstructure. Can J Fish Aquat Sci 42:899-908. doi:10.1139/f85-114

Parker RR (1971) Size selective predation among juvenile salmonid fishes in a British-Colombia inlet. J Fish Res Board Can 28:1503-1510 
Peterson NP (1982) Immigration of juvenile coho salmon (Oncorhynchus kisutch) into riverine ponds. Can J Fish Aquat Sci 39:1308-1310

Reisner M (1986) Cadillac desert : the American West and its disappearing water. Viking, New York, N.Y

Rich AA (1987). Report on studies conducted by Sacramento County to determine the temperatures which optimize growth and survival in juvenile chinook salmon (Oncorhynchus tshawytscha). McDonough, Holland \& Allen, Sacramento, Ca

Ruckelshaus MH, Levin P, Johnson JB, Kareiva PM (2002). The Pacific Salmon wars: What science brings to the challenge of recovering species. Annu Rev of Ecol and Syst 33:665-706

Schlosser IJ (1987) The role of predation in age- and sizerelated habitat use by stream fishes. Ecology 68:651-659. doi: $10.2307 / 1938470$

Scrivener JC, Brown TG, Andersen BC (1994) Juvenile chinook salmon (Oncorhynchus tshawytscha) utilization of Hawks Creek, a small and nonnatal tributary of the Upper Fraser River. Can J Fish Aquat Sci 51:1139-1146. doi:10.1139/f94-113

Secor DH, Dean JM, Laban EH (1992) Otolith removal and preparation for microstructural examination. In: Stevenson DK, Campana SE (eds) Otolith microstructure examination and analysis. Canadian Special Publication of Fisheries \& Aquatic Sciences 117, pp 19-57

Shreffler DK, Simenstad CA, Thom RM (1992) Foraging by juvenile salmon in a restored estuarine wetland. Estuaries 15:204-213. doi:10.2307/1352693

Simenstad CA, Cordell JR (2000) Ecological assessment criteria for restoring anadromous salmonid habitat in Pacific Northwest estuaries. Ecol Eng 15:283-302. doi:10.1016/S0925-8574(00)00082-3

Sommer TR, Nobriga ML, Harrell WC, Batham W, Kimmerer WJ (2001) Floodplain rearing of juvenile chinook salmon: evidence of enhanced growth and survival. Can J Fish Aquat Sci 58:325-333. doi:10.1139/cjfas-58-2-325

Swales S, Levings CD (1989) Role of off-channel ponds in the life cycle of coho salmon (Oncorhynchus kisutch) and other juvenile salmonids in the Coldwater River, British Columbia. Can J Fish Aquat Sci 46:232-242. doi:10.1139/ f89-032

Swales S, Lauzier RB, Levings CD (1986) Winter habitat preferences of juvenile salmonids in two interior rivers in British Columbia. Can J Zoology-Revue Canadienne De Zool 64:1506-1514. doi:10.1139/z86-225

Tabor RA, Footen BA, Fresh KL, Celedonia MT, Mejia F, Low DL (2007) Smallmouth bass and largemouth bass predation on juvenile chinook salmon and other salmonids in the Lake Washington Basin. N Am J Fish Manage 27:1174-1188. doi:10.1577/M05-221.1

Vander Zanden MJ, Vadeboncoeur Y (2002). Fishes as integrators of benthic and pelagic food webs in lakes. Ecology 83:2152-2161

Welcomme RL 1979. Fisheries ecology of floodplain rivers. Longman, London; New York

Wigington PJ, Ebersole JL, Colvin ME, Leibowitz SG, Miller B, Hansen B, Lavigne HR, White D, Baker JP, Church MR, Brooks JR, Cairns MA, Compton JE (2006) Coho salmon dependence on intermittent streams. Front Ecol Environ 10:513-518. doi:10.1890/1540-9295(2006)4[513: CSDOIS]2.0.CO;2

Wright PJ, Metcalfe NB, Thorpe JE (1990). Otolith and somatic growth-rates in Atlantic Salmon parr, Salmo-salar L evidence against coupling. J Fish Biol 36:241-249

Yoshiyama RM, Gerstung ER, Fisher FW, Moyle PB (2000) Chinook salmon in the California Central Valley: an assessment. Fisheries 25:6-20. doi:10.1577/1548-8446 (2000)025<0006:CSITCC $>2.0 . C O ; 2$ 